\title{
З ДОСВІДУ ЗАСТОСУВАННЯ КЕЙС-МЕТОДУ ТА ПРОАКТИВНОЇ ПРЕЗЕНТАЦІЇ ПРИ ЧИТАННІ ЛЕКЦІЙНОГО МАТЕРІАЛУ
}

\author{
В. П. Пішак, О. І. Захарчук, М. І. Кривчанська \\ Буковинський держсавний медичний університет МОЗ Украӥни, м. Чернівиі
FROM EXPERIENCE OF CASE-METHOD APPLICATION AND PROACTIVE PRESENTATION AT READING OF LECTURES \\ V. P. Pishak, O. I. Zakharchuk, M. I. Kryvchanska \\ Bukovynian State Medical University of MPH of Ukraine, Chernivtsi
}

\begin{abstract}
Кейс-метод та проактивна презентація з використанням так званого методу “вільного конспекту" лекції має за мету створити особисту зацікавленість студентів тому, що перед аудиторісю будуть поставлені питання, на які вони зможуть відповісти лише завдяки інформації, отриманій на лекції. Презентація зобов'язує за короткий проміжок часу надати великий об'єм інформації та подій. Вільний конспект вимагає вміння самостійно, чітко і коротко формулювати основні положення, для чого необхідне глибоке осмислення матеріалу, великий та активний словниковий запас.

Case-method and proactive presentation using the so-called method of "free synopsis" of lecture aims to create a personal interest in students that the audience will put questions to which they can be answered only through the information received at the lecture. Presentation obliges for a small period of time to provide a large amount of information and events. Free outline requires the ability to independently formulate a clear and concise basic provisions, which requires a deep understanding of the material, a large and active vocabulary.
\end{abstract}

Вступ. Сучасні європейські й світові тенденції розвитку вищої освіти та напрямки діяльності Болонського процесу безперечно вказують на те, що вища освіта в Україні $є$ інноваційною галуззю, котра, за своєю природою, потребує розмаїття поглядів і підходів до проведення досліджень, викладання навчального матеріалу і управління.

Викладання навчального матеріалу постійно потребує підвищення професійного рівня, педагогічної майстерності, загальної культури викладача, вдосконалення та уведення в навчальний процес нових форм $i$ методів з метою забезпечення умов для засвоєння студентами, курсантами, слухачами, стажистами, клінічними ординаторами, аспірантами навчальних програм на рівні обов'язкових вимог щодо змісту, рівня та обсягу освіти, сприяння розвиткові здібностей студентів [1].

На сьогодні існує велика різноманітність класифікацій методів викладання навчального матеріалу. Наприклад, поділ методів, який базується на характері дій студентів: активні (якщо студенти працюють самостійно - практичні заняття, робота з книгою) та пасивні (якщо студенти слухають і дивляться - розповідь, бесіда, лекція, демонстрація). Одна 3 нещодавно запропонованих класифікацій за основу бере ступінь розвитку самостійності в пізнавальній діяльності студентів. У цій системі першим називається пояснювально-ілюстративний метод, при якому студент засвоює готові знання, які йому подаються в різній формі (розповідь, лекція, демонстрація); далі - евристичний метод (частково-пошуковий), тобто метод частково самостійних відкриттів, здійснюваних студентами самостійно за вказівками та за направляючої ролі викладача; і третій метод дослідницький (може застосовуватися як в аудиторії - експеримент, і при самостійній науково-дослідницькій роботі - в науковій лабораторії чи клініці). На якість викладу лекційного матеріалу впливає багато чинників: лектор (презентатор), аудиторія, часові рамки, місце проведення та ін. [2].

Основна частина. Серед активних форм навчання (табл. 1) широкого застосування набуває проблемне навчання - це така форма навчання, в процесі якої студенти залучаються до вирішення проблем. Елементи проблемного навчання були закладені в евристичних бесідах Сократа, розробках уроків для Еміля та Жан-Жака Руссо, а також у “Педагогічній антропології” К. Д. Ушинського. Історія власне

\footnotetext{
() В. П. Пішак, О. І. Захарчук, М. І. Кривчанська
} 
Таблиця 1. Методи активного навчання (за: Богданова О. К., 2003)

\begin{tabular}{|l|l|l|}
\hline \multicolumn{1}{|c|}{ Неімітаційні } & \multicolumn{2}{c|}{ Імітаційні } \\
\cline { 2 - 3 } & \multicolumn{1}{|c|}{ неігрові } & \multicolumn{1}{|c|}{ ггрові } \\
\hline Проблемна лекція & Аналіз конкретних виробничих ситуацій & Імітація на тренажері \\
\hline Евристична бесіда & Рішення ситуаційних задач & Розігрування ролей \\
\hline Пошукова лабораторна робота & $\begin{array}{l}\text { Вправи-дії за інструкцією (лабораторна } \\
\text { робота, практична робота) }\end{array}$ & Ділова гра \\
\hline Дослідницький метод & Виконання індивідуальних завдань & \\
\hline $\begin{array}{l}\text { Самостійна робота з навчальною програмою } \\
\text { (програмоване навчання) }\end{array}$ & & \\
\hline Самостійна робота з книгою. Діалоги & & \\
\hline Словесно-логічний метод & & \\
\hline
\end{tabular}

проблемного навчання бере початок після введення так званого “дослідницького” методу, більшість правил якого були розроблені Джоном Дьюї.

При проблемному навчанні викладач не передає знання у готовому вигляді, а ставить перед студентом завдання, зацікавлює його, збуджує у нього бажання знайти засоби для його розв'язання. У пошуках цих засобів і шляхів студент й отримує нові знання. Ключовим поняттям проблемного навчання $є$ проблемна ситуація. Вона виникає тоді, коли для осмислення чогось або виконання якихось необхідних дій людині не хватає наявних знань або відомих способів дій, тобто має місце протиріччя між знанням і незнанням. Для того щоб у студентів 3'явилося бажання вирішувати проблемну ситуацію, необхідно дотримуватися двох умов: змістовна сторона ситуації має викликати певну зацікавленість у студентів i вони мають відчувати, що вирішення проблеми в цілому їм посильне, бо частина необхідних знань у них $\epsilon$. Після прийняття проблемної ситуації до вирішення та оформлення ії в словесну форму, яка відокремлює відоме від невідомого, вона перетворюється в проблемне завдання, в процесі вирішення якого відбувається отримання та засвоєння нових знань.

Не всяке навчальне завдання $\epsilon$ проблемним. Проблема - це пошукове завдання, яке не має стандартного рішення (схеми, алгоритму чи зразка), і яке вимагає пошуку нових знань для його вирішення.

Проблемне питання відрізняється від звичайного тим, що в ньому є приховане протиріччя, що воно відкриває можливості нетипових відповідей, неоднозначного вирішення і що в минулому досвіді того, кому воно задається, немає готової схеми рішення. Наявність протиріччя як висхідного моменту виникнення проблемності - найважливіша характеристика проблемного навчання в цілому та всіх пов'язаних 3 ним понять.

Прийнято вважати, що проблемне навчання здійснюється в трьох основних формах, які різняться за ступенем пізнавальної самостійності в них студентів: проблемного викладення матеріалу, частково-пошукової та самостійної навчально-дослідницької діяльності.

Найменша пізнавальна самостійність учнів має місце при проблемному викладанні: повідомлення нового матеріалу здійснюється самим викладачем (лекція, розповідь, бесіда), але студенти при цьому залучаються ним до активної розумової діяльності. При цьому проблемність створюється цілою низкою прийомів, мета яких викликати у студентів "співпереживання", зацікавити їх розкриттям перед ними усього процесу виникнення та вирішення проблеми.

В умовах частково-пошукової діяльності робота направляється викладачем в основному за допомогою спеціальних питань, які стимулюють студента до самостійних роздумів, активного пошуку відповіді (“А як би ви вирішили цю проблему?”, “А як можна перевірити, яка 3 цих здогадок правильна?”, “'Зверніть увагу на такі особливості...”, “Як можна пов’язати будову ... і функцію?").

Науково-дослідницька діяльність - це повністю самостійний пошук рішень студентом. Вона передбачає наявність проблеми і виконання усієї послідовності пошукових дій, необхідних для ії̈ вирішення (експеримент в лабораторії чи клініці, написання доповіді чи реферату, розробка та висвітлення питання на засіданні наукового гуртка тощо).

При всіх формах проблемного навчання завжди має місце розробка викладачем від початку і до кінця всього процесу вирішення проблеми. Робота ця розпочинається з вирішення питання про те, чи дозволяє навчальний матеріал створити проблемну ситуацію. Чи є необхідність у їі створенні? I ще цілий ряд наступних питань - від вибору точного формулювання проблеми до підбору способів перевірки вірності іiі вирішення. Проблемне навчання не може перетворюватися в єдину чи навіть домінуючу форму навчання. Воно повинно застосовуватися у поєднанні 3 усіма іншими усталеними формами навчання [3]. 
Завдання лектора - сформувати у слухачів певну думку про отриману інформацію, спонукати студентів до активної роботи. Як правило, на лекції присутні не менше 200 чоловік, за визначенням Е. Джей і Р. Джей, це середня аудиторія. Для середньої аудиторії рекомендується проактивна презентація - лектор (презентатор) передбачає результат і вживає заходів, щоб його забезпечити [4].

Презентації поділяються на проактивні та інтерактивні.

Проактивна презентація - презентатор передбачає результат та використовує засоби, щоб його забезпечити. Все залежить від прийнятих раніше рішень, а не від того, яким чином розвивається ситуація. Головна дійова особа - це презентатор. Саме така форма є найбільш ефективною для зовнішніх презентацій з великою або середньою аудиторією.

Інтерактивна презентація - доповідач і аудиторія взаємодіють на рівних. Відбувається обмін інформацією. Ситуація відповідно може коригуватися по ходу доповіді залежно від висунутих аудиторією пропозицій, ідей, реакцій. Із чого ми можемо дійти висновку, що такий тип презентації є оптимальним для малих аудиторій.

На студентських лекціях ми знаємо віковий контингент аудиторії, припускаємо рівень їх підготовки і зацікавленості в отриманій інформації. Однак слід визначитися, яким чином буде організований зворотний зв'язок, щоб переконатися, наскільки добре засвоєна наша інформація.

Виникає проблема не тільки сприйняття, а й бажання студента знати навчальний матеріал. Видатний американський соціальний психолог сучасності Стенлі Мілграм вказує, що “по всій видимості, (при складанні іспитів) ми готові до сприйняття стресу, напруги та впливу на самооцінку. Але коли справа стосується процесу отримання нових знань, як же мало терпимості ми виявляємо" [5].

Впровадження нових технологій у навчальний процес завжди вважалося прогресивним кроком і підвищувало мотивацію навчання. Сьогодні до інноваційних технологій можна віднести і використання комп'ютерних моделюючих систем, і впровадження ситуаційних, так званих, кейсових технологій, i вирішення фахових задач за допомогою комплексного використання знань із загальноосвітніх та фахових дисциплін.

Впровадження сучасних інтерактивних методів навчання вимагає глибокого залучення студентів до навчального процесу.

Кейс-метод грунтується на принципах, які фактично змушують переглянути роль викладача і студен- та. Зобов'язання викладача при застосуванні кейсметоду полягає в тому, щоб створити у навчальної аудиторії такі умови, які б дозволили розвинути у студентів вміння критично мислити, аналізувати, спонукати їх до того, щоб у процесі дискусії поділитися власними думками, ідеями, знаннями та досвідом. Зобов'язання студента полягає в тому, щоб, збагачуючи своєю творчою енергією навчальний процес, прийняти на себе частку відповідальності за його результативність. При цьому студенти повинні усвідомлювати, що викладач знаходиться в аудиторії для того, щоб, допомогти їм, і вони мають скористатися цим у повній мірі, проте основна відповідальність за те, чого вони навчились, лежить на них [6].

Завданням кейс-методу є не просто передача знань, а навчання студентів здатності справлятися 3 такими унікальними та нестандартними ситуаціями, які вимагають знань з багатьох наук, які, як правило, виникають в реальному житті і вимагають вирішення таких проблем, що реально виникли чи можуть виникнути й потребують прийняття системного рішення.

Використання цього інтерактивного освітнього методу, що вимагає активної індивідуальної участі студентів і не передбачає єдиної "правильної" відповіді, є дуже природним для суспільства з невеликою владною дистанцією, домінуючими цінностями індивідуалізму і слабким прагненням уникнути невизначеності.

Кейс-метод є дуже ефективним у розвитку навичок ідентифікації фахових проблем, систематизації і аналізу викладених фактів та розробки альтернативних рішень. Творче і аналітичне мислення стає необхідною рисою сучасного медика за умов зростання конкуренції.

У найбільш загальному вигляді процес розробки будь-якого кейсу може бути представлений як такий, що передбачає проходження таких етапів, як: підготовка загального плану кейсу; проведення досліджень, необхідних для підготовки кейсу; написання вихідного варіанта кейсу; обговорення кейсу 3 фахівцями і редагування; підготовка нотаток для викладачів щодо того, яким чином доцільно презентувати кейс; презентація кейсу в навчальній аудиторії i редагування як самого тексту, так і нотаток для викладачів, якщо це є необхідним; розповсюдження кейсу.

Індивідуальний аналіз кейсу і його обговорення в групі містять більші можливості для розвитку фахової майстерності, ніж заучування підручника чи конспекту лекцій. 
Даючи студентам завдання у формі кейсів, ми відкриваємо їм значно більшу можливість поділитися своїми знаннями, досвідом і уявленнями, тобто навчитися не тільки у викладача, а й один в одного. Такий метод піднімає впевненість студентів у собі, у своїх здібностях. Студенти активно вчаться слухати один одного і точніше висловлювати свої думки.

В умовах глобалізації економіки кейсів метод допоможе краще розуміти психологію наших іноземних партнерів, для яких цей метод складає основу їх вищої освіти.

При застосуванні кейс-методу формуються такі навички, як спостереження, відбір даних, ідентифікація проблеми, розробка щодо прийняття альтернативних рішень, спілкування, мотивація.

Таким чином, світовий досвід підготовки фахівців у вищій школі доводить, що найголовнішою навичкою, яку здобуває студент під час навчання, $є$ вміння під професійним кутом зору сприймати будь-яку наочну, вербальну інформацію, самостійно осмислювати, приймати рішення, оцінюючи його можливі наслідки, визначати оптимальні шляхи реалізації цього рішення [7].

Аудиторія більше піддається впливу аргументованого повідомлення, якщо піддає його систематичному аналізу, іншими словами, студенти будуть краще сприймати сказане лектором, якщо вони стануть замислюватися над інформацією і будуть іiі аналізувати. Таке відбувається тільки в тому випадку, якщо аудиторія мотивована це робити і має таку можливість, або коли мова йде про суб'єктивно значущі речі. Як правило, створити особисту зацікавленість вдається завдяки тому, що перед аудиторією будуть поставлені деякі питання, на які вони зможуть відповісти лише завдяки інформації, отриманій на лекції.

Презентація зобов'язує нас, як правило, за невеликий період часу надати великий набір інформації і подій.

Написання лекції частіше містить текстовий варіант фіксування одержуваної інформації. Ті схеми, рисунки, на які посилався лектор, втрачаються, тобто одержувана інформація фіксується частково, студент швидко стомлюється, а це викликає негативне ставлення, оскільки в цьому випадку людина увімкне свої системи захисту і стане нам недоступною.

Для усунення виявлених недоліків презентації нами використаний метод “вільного конспекту”.

Вільний конспект поєднує виписки, цитати, іноді тези; частина його тексту може бути забезпечена планом, малюнком, фотографією. Вільний конспект вимагає вміння самостійно, чітко і коротко форму- лювати основні положення, для чого необхідні глибоке осмислення матеріалу, великий та активний запас слів. Самоскладання цього виду конспекту прекрасно розвиває зазначені вище якості. Можна сказати, що вільний конспект, мабуть, найбільш повноцінний вид конспекту, якщо врахувати ту користь, яку отримують слухачі хоча б уже $з$ самого процесу його складання.

Для поліпшення повноти і якості отримуваної інформації необхідно надавати студентам перед лекцією матеріал у вигляді окремих слайдів з лекції. Біля кожного слайда залишати вільне чисте поле на аркуші, на якому самі студенти по ходу лекції заносили б текстову інформацію, або пояснення до представленої схеми.

На думку студентів, ця форма роботи дає їм можливість проаналізувати отриману інформацію, взяти участь в обговоренні деяких питань, що виникають під час лекції, знижує нервову напругу, дозволяє легше сприймати інформацію, а в подальшому більш точно ії відтворювати.

Робота з інформацією вимагає спеціальних підходів. Цілий ряд досліджень комунікаційних процесів у студентських колективах показав, що викладач від свого студента чи науковий керівник від дисертанта може добитися розуміння не більш ніж 60 \% інформації зі складної проблеми (мова йде саме про вищий менеджмент, відповідальних і серйозних студентів та молодих науковців). У разі передачі інформації за допомогою письмових джерел відсоток втрат ще вищий. Поєднання різних інформаційних каналів знижує втрати [8]. Це очевидно з буденної практики: у кожної людини свій механізм сприйняття. Хтось легко схоплює думку з півслова, не дуже прагнучи відкрити книгу. Хтось віддає перевагу сприйняттю текстової інформації. Для різних спільнот теж необхідні різні способи комунікативного впливу, що особливо $€$ актуальним для студентського середовища.

Висновки: 1. При викладанні навчального матеріалу ефективним для розвитку навичок ідентифікації фахових проблем, систематизації й аналізу викладених фактів та розробки альтернативних рішень кейсметод розвиває творче й аналітичне мислення студентів.

2. Проактивна презентація надає можливість студентам аналізувати отриману інформацію, взяти участь в обговоренні деяких питань, що виникають під час лекції, знижує нервову напругу, дозволяє легше сприймати інформацію та більш точно ііі відтворити у майбутньому. 


\section{ВДОСКОНАЛЕННЯ ВИЩОЇ МЕДИЧНОЇ ОСВІТИ}

\section{Лiтература}

1. Про освіту: Закон України № 1060-XII, із змінами від 11 червня $2008 \mathrm{p}$.

2. Богданова О. К. Інноваційні підходи до викладання біології : навч. посіб. / О. К. Богданова. - Х. : Основа, 2003.128 с. - (Бібліотека журналу “Біологія” ; вип. 9).

3. Активні форми та методи навчання біології : навч. посіб. / уклад. К. М. Задорожний. - Х. : Основа, 2008. - 123 с. (Бібліотека журналу “Біологія”; вип. 12(72)).

4. Джей Э. Эффективная презентація / Э. Джей ; пер. с англ. -Минск : Амалфея, 1997.-208 с.

5. Милграм С. Эксперимент в социальной психологии /
С. Милграм. - СПб. : Издательство “Питер”, 2000. - 336 с.

6. Ковжога С. О. Сучасні освітні технології та методи їх використання в навчальному процесі / С. О. Ковжога, А. М. Полєжаєв, С. А. Тузіков. - http://www.rusnauka.com/ 8_NMIW_2008/Pedagogica/28601.doc.htm

7. Воркут Т. А. Роль кейс-методу в підготовці фахівців 3 логістики : аналіз світового досвіду / Т. А. Воркут // Ринок послуг комплексних транспортних систем та прикладні проблеми логістики. - Київ, 2000.-С. 55-61.

8. Почепцов Г. Г. Паблик рилейшнз для профессионалов / Г. Г. Почепцов. - М. : Рефл-бук: Ваклер, 2005. -638 с. 